\title{
FOREIGN TRADE COMMODITY FLOWS ACROSS THE EASTERN BOUNDARY OF POLAND
}

\author{
BARBARA SZEJGIEC \\ Institute of Geography and Spatial Organization \\ Polish Academy of Sciences \\ Twarda 51/55, 00-818 Warszawa, Poland \\ e-mail: bar.szej@twarda.pan.pl
}

\begin{abstract}
The paper presents the characterisation of turnover in foreign trade across the Polish segment of eastern boundary of the European Union. On the basis of data from the Ministry of Finance the variability was analysed of the volume of foreign trade in the years 2005 and 2007, considering different state borders, border crossing points and directions of trade. These considerations have been broadened by the analysis of the unregistered turnover of the peri-border trade, this analysis being based on the data from the Central Statistical Office (GUS).
\end{abstract}

Key words: commodity flows, foreign trade, eastern border of Poland

\section{INTRODUCTION}

Processes, associated with cross-border traffic, of both people and of goods (registered as well as unregistered), have very high importance for the socio-economic development of the transboundary areas. There has also been an increasing interest in the Polish segment of the outer boundary of the European Union (with Russiathe Kaliningrad district, with Belarus and Ukraine), especially after Poland joined the Schengen treaty zone in 20071.

The purpose of this report is to present the results of study of the commodity flows taking place across the Polish segment of the EU outer boundary. The report outlines, first, the method of processing the data, obtained from the Ministry of

\footnotetext{
1 An example is provided by the project, carried out at the Institute of Geography and Spatial Organization of the Polish Academy of Sciences in the years 2007-2009, entitled Person and commodity flows across the Polish segment of the outer boundary of the European Union. The present report makes use of the statistical data, acquired during this project.
} 
Finance (MF further on), for carrying out the analysis, then the basic results are provided of the directional analysis of the geographical structure of Polish foreign trade according to the boundaries crossed between Poland and non-EU countries and according to the border crossing points, and the issue of investigation of the unregistered cross-border commodity flows across the eastern border is discussed (based on the data from the Central Statistical Office, GUS).

Analysis of data, concerning the directions of trade with the neighbouring countries constitutes, in terms of the subject matter, a continuation of studies, conducted by T. Komornicki (Komornicki 2000). The analysis is founded on the Extrastat data, i.e. the system of statistics on commodity trade with countries from the outside of the EU, whose source is the information from the customs declarations-the unified administrative document SAD (which functions in Poland since 1992). Starting with 2004, information on the border traffic of goods between Poland and the EU countries is inaccessible (the Intrastat system, functioning within the area of the EU countries, does not contain data on the customs clearance locations). The statistics of foreign trade (irrespective of the country of origin / destination of goods) generally contain the flows of goods, which, in a permanent manner, increase or decrease the resources of a country (as well as goods, which are subject to quality enhancement), but do not include the goods that are transported across the territory of the country (transit) or only temporarily brought to / transported out of the country (Grębowiec 2005).

The database, acquired from the Customs Department of the Ministry of Finance (MF), contains the data on the location of dispatching of the goods, location of destination, location of the ultimate customs clearance (the latter having served for aggregating data according to the border of clearance and border crossing points) and on the value of goods in Polish zlotys (Komornicki 2000). The time span of the analysis here reported, in view of data availability, encompasses the years 2005 and 2007.

Initially, the statistical database was subject to logical data control. Data on the Polish foreign trade across the eastern border are characterised by a relatively high quality (they are somewhat overestimated in the case of export-at the level of $103.2 \%$ to $108.3 \%$ of the export value according to the official GUS statistics, and mainly underestimated for import, between $80.6 \%$ and $98.9 \%$ of the import value according to GUS, Table 1).

The scale of differences may also result from the fact that the value of trade turnover in Polish zlotys was converted to US dollars conform to the average annual exchange rate of the Polish National Bank, valid for a given year (in analogy to the preceding studies of the type), in order to enable potential international comparisons.

Data from the dataset acquired have been aggregated at two levels, according to the boundary of customs clearance (with Belarus, Ukraine and Russia-the Kaliningrad district) and according to the border crossing points (single crossing points or groups of crossing points). Altogether 20 border crossing points were distinguished: 
Table 1. Foreign trade value between Poland and selected countries, in ' 000 USD, in the years 2005 and 2007

\begin{tabular}{|c|c|c|c|c|c|c|}
\hline \multirow{2}{*}{ Data source } & \multicolumn{2}{|c|}{ Belarus } & \multicolumn{2}{|c|}{ Russia } & \multicolumn{2}{|c|}{ Ukraine } \\
\hline & 2005 & 2007 & 2005 & 2007 & 2005 & 2007 \\
\hline \multicolumn{7}{|c|}{ Export } \\
\hline $\begin{array}{l}\text { Ministry of } \\
\text { Finance (MF) }\end{array}$ & 750706 & 1161883 & 4173921 & 6640347 & 2804001 & 5850359 \\
\hline GUS & 722074 & 1121485 & 3960510 & 6432276 & 2588213 & 5511254 \\
\hline $\begin{array}{l}\text { Ratio of MF to } \\
\text { GUS value in } \%\end{array}$ & 104.0 & 103.6 & 105.4 & 103.2 & 108.3 & 106.2 \\
\hline \multicolumn{7}{|c|}{ Import } \\
\hline MF & 789120 & 1127796 & 8575651 & 14348751 & 936682 & 1818007 \\
\hline GUS & 979513 & 1139975 & 8985501 & 14352843 & 1020986 & 1693541 \\
\hline $\begin{array}{l}\text { Ratio of MF to } \\
\text { GUS value in } \%\end{array}$ & 80.6 & 98.9 & 95.4 & 100.0 & 91.7 & 107.3 \\
\hline
\end{tabular}

Source: own elaboration on the basis of data from GUS and materials from MF.

Gronowo, Braniewo, Bezledy, Gołdap, Połowce, Kuźnica, Bobrowniki, Siemianówka, Czeremcha, Terespol, Sławatycze, Dorohusk, Zosin, Hrubieszów, Hrebenne, Werchrata, Korczowa, Przemyśl, Medyka, Krościenko, of which some selected ones were put together (Gronowo/Braniewo, Połowce/Czeremcha, Hrubieszów/Zosin, Hrebenne/Werchrata).

The data, concerning the customs clearance locations inside the country (including the airports) and along the sea border, as well as the undetermined locations of clearance, have not been subject to detailed analysis and were aggregated as the "remaining ones". Besides, the analysis did not concern the fuels (oil and gas), transported via pipelines, i.e. the permanent transport installations.

\section{FOREIGN TRADE ACCORDING TO THE BOUNDARY OF CLEARANCE}

Of the three boundaries considered here, in 2005, goods of highest total valueroughly $10 \%$ (this share being much higher for exports-15\%, than for imports-5\%) of the total trade value (from the Extrastat system) were transported across the Ukrainian segment of the border. Trade across the border with Belarus was also significant $-8 \%$ of the total trade turnover (more than $11 \%$ for exports). The share of trade across the border with the Kaliningrad district was marginalonly $1.5 \%$ (pipeline transport excluded, as indicated). Jointly, the three segments of the boundary of Poland accounted for close to $20 \%$ of total foreign trade. For the assumptions mentioned here a positive trade balance was observed over all three segments of the boundary (Table 2). 
Table 2. Foreign trade turnover according to the border of clearance in 2005

\begin{tabular}{|l|r|r|r|r|r|r|r|}
\hline \multirow{2}{*}{$\begin{array}{c}\text { Boundary } \\
\text { with: }\end{array}$} & \multicolumn{2}{|c|}{ Total turnover } & \multicolumn{2}{c|}{ Export } & \multicolumn{2}{c|}{ Import } & Balance \\
\cline { 2 - 9 } & in '000 USD & in \% & in '000 USD & in \% & in '000 USD & in \% & in '000 USD \\
\hline Russia & 675759 & 1.5 & 578341 & 2.7 & 97418 & 0.4 & 480922 \\
\hline Belarus & 3785821 & 8.1 & 2434653 & 11.2 & 1351168 & 5.5 & 1083484 \\
\hline Ukraine & 4500234 & 9.7 & 3311511 & 15.2 & 1188723 & 4.8 & 2122788 \\
\hline other & 37538373 & 80.7 & 15441046 & 70.9 & 22097326 & 89.3 & -6656280 \\
\hline Totals & 46500187 & 100.0 & 21765550 & 100.0 & 24734636 & 100.0 & -2969086 \\
\hline
\end{tabular}

Source: own elaboration on the basis of materials from MF.

Then, in 2007, the share of trade turnover across the three segments of the boundary of Poland here considered increased to more than $20 \%$ (in exports alone also roughly 20\%). The value of trade increased, as well, for all the segments considered, in comparison with 2005. The highest dynamics of the trade turnover in the years 2005-2007 was observed at the Ukrainian border (this dynamics being much higher for inward movement of goods). The tendency towards the positive trade balance persisted also in 2007 (Table 3).

Table 3. Foreign trade turnover according to the border of clearance in 2007

\begin{tabular}{|l|r|r|r|r|r|r|r|}
\hline \multirow{2}{*}{$\begin{array}{c}\text { Boundary } \\
\text { with: }\end{array}$} & \multicolumn{2}{|c|}{ Total turnover } & \multicolumn{2}{c|}{ Export } & \multicolumn{2}{c|}{ Import } & Balance \\
\cline { 2 - 9 } & in '000 USD & in \% & in '000 USD & in \% & in '000 USD & in \% & in '000 USD \\
\hline Russia & 993310 & 1.3 & 875888 & 2.8 & 117422 & 0.3 & 758465 \\
\hline Belarus & 6191324 & 8.3 & 4242123 & 13.7 & 1949201 & 4.4 & 2292923 \\
\hline Ukraine & 8853107 & 11.8 & 6114342 & 19.7 & 2738764 & 6.2 & 3375578 \\
\hline other & 58965009 & 78.6 & 19787084 & 63.8 & 39177926 & 89.1 & -19390842 \\
\hline Totals & 75002750 & 100.0 & 31019437 & 100.0 & 43983313 & 100.0 & -12963877 \\
\hline
\end{tabular}

Source: own elaboration on the basis of materials from MF.

\section{FOREIGN TRADE ACCORDING TO BORDER CROSSING POINTS}

From among the border crossing points accounted for, the most important one in 2005 was Terespol, through which goods of total value of 2.4 billion USD were altogether transported (5.8\% share in exports to all the eastern neighbours of Poland through all the crossing points considered, and $4.6 \%$ in imports). In terms of exports high shares were also observed for the crossing points in Medyka, Korczowa and Dorohusk (goods of total value exceeding 800 million USD were transported, equivalent to shares in export at around 4\%), while in terms of imports-Medyka (more than 500 million USD of value, i.e. $2.3 \%$ of imports). Of the crossing points along the boundary with Russia the most important was the one in Bezledy (trade turnover of approximately 0.5 million USD). 
In 2007, along with the increase of trade turnover at all the border crossing points (except for the crossings Połowce/Czeremcha for exported and imported goods and Sławatycze for exported goods) the significance of individual border crossings changed.

The highest increase of turnover in the years 2005-2007 was registered at the crossing points with the lowest volume of foreign trade-in Krościenko (more than tenfold increase!), as well as in Kuźnica and Dorohusk (more than twofold increase). In terms of exported goods the increase of significance was the most pronounced for Terespol (6.4\% share in trade turnover with eastern neighbours of Poland across the border crossings considered), Dorohusk (5.7\%), Medyka (5.5\%) and Korczowa $(5.4 \%)$. On the other hand, in imports, there has been a slight increase of significance at a couple of crossing points, e.g. Hrubieszów/Zosin (2.2\%) and Dorohusk $(1.1 \%)$. The significance of the remaining crossing points decreased, and there has been a relatively important drop at the crossing point in Terespol (from 4.5 to $3.4 \%$ ), (Figure 1).

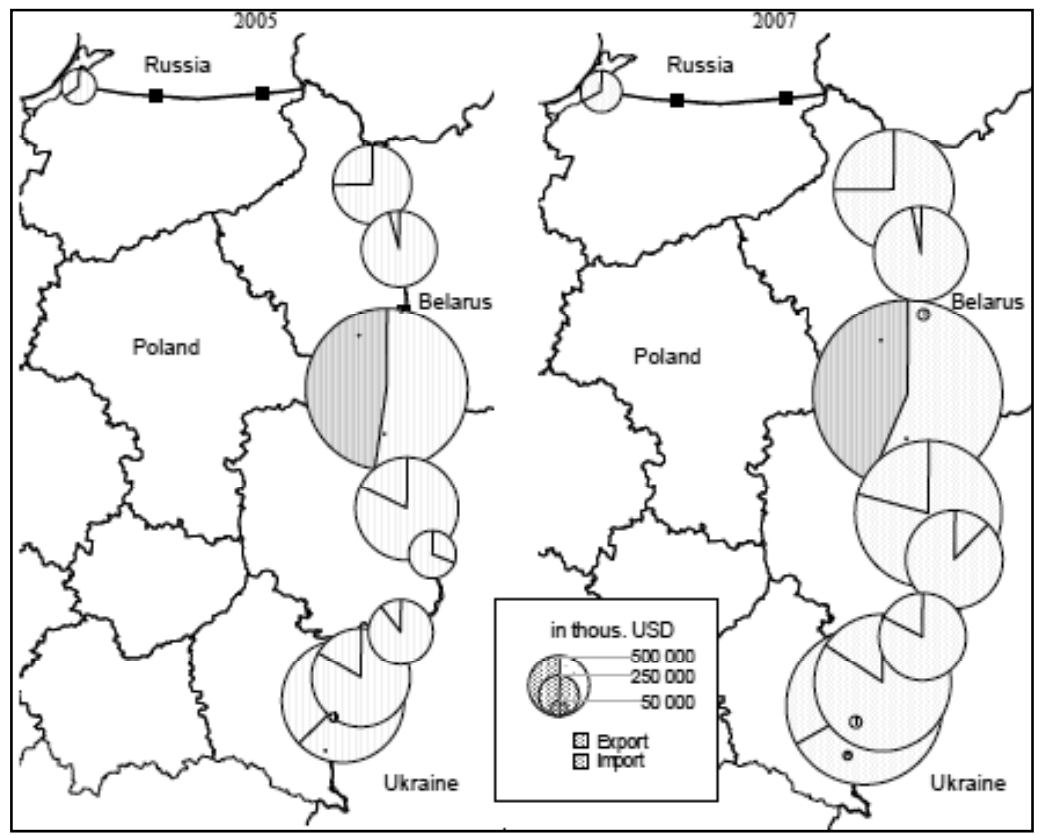

Figure 1. Foreign trade turnover according to border crossing points in ' 000 USD in the years 2005 and 2007

Source: own elaboration on the basis of materials from MF.

\section{DIRECTIONAL STRUCTURE OF FOREIGN TRADE}

In the analysis of directional structure of foreign trade attention was focussed on countries directly bordering upon Poland across the outer boundary of the European Union, in order to verify to what extent trade with them takes place directly through the boundaries with these countries. 
Thus, in 2005, at all the border crossing points to Russia the shares of trade with Russia in respective totals ranged between $81.5 \%$ and $100 \%$. At the crossings of Gronowo/Braniewo a significant share of imports from Belarus was observed (more than $11 \%$ ). Border crossings to Belarus, where marginal share of trade with Ukraine was observed, were characterised by an almost even concentration of the shares of trade with Belarus (in export - the highest share at the crossing in Sławatycze-more than $69 \%$, in import - the highest at the crossing in Połowce/Czeremsze-in excess of $82 \%$ ) and Russia (in export-the highest at the crossing in Bobrowniki-almost $80 \%$, and in import-also in Bobrowniki-68\%). On the other hand, at the border crossings to Ukraine very high concentration of trade with this neighbouring country was observed (in export-the highest in Krościenko-close to 100\%, then in Dorohusk-89\%, and in import-also in Dorohusk-79\%). In addition, there were some border crossing points along the boundary with Ukraine, where a relatively high share of trade with Russia was noted: for import-in Hrubieszów/Zosin-close to 27\%, and in Medyka—almost 19\%, and for export—Przemyśl—28\%.

In 2005, across the Polish-Russian border, goods were transported accounting for $13.2 \%$ of Polish export to Russia, and for $1.0 \%$ of imports from Russia. The share of trade with Belarus at this border-in relation to total value of trade with this country-was small ( $0.1 \%$ of total exports and $1.0 \%$ of imports). With respect to trade with Ukraine the respective values were insignificant.

On the Polish-Belarusian border, domination of the bilateral trade flows was observed in total. They accounted for $94.0 \%$ of Polish exports to Belarus and for $82.4 \%$ of imports from Belarus. On the top of this, though, trade with Russia is taking place across the same border, amounting to $36.0 \%$ of Polish exports to Russia and $6.4 \%$ of imports from Russia. In addition, a small part of goods imported from Ukraine was transported across the border with Belarus $(0.8 \%$ of the total value of imports from Ukraine).

Trade flows across the border with Ukraine were even more concentrated on bilateral flows of goods. They accounted for $93.4 \%$ of Polish exports to Ukraine and $80.2 \%$ of imports from Ukraine. Trade with Belarus along this border accounted for roughly $1.7 \%$ of both total exports to and imports from Belarus, while for trade with Russia the respective numbers were $2.5 \%$ and $2.0 \%$ (Table 4 ).

By 2007 the structure of trade with Russia, Belarus and Ukraine according to border crossings has not changed significantly. There was a perceptible increase of trade value with Belarus at the crossing points of Kuźnica, Bobrowniki and Dorohusk. Trade with Russia featured relatively higher turnover at the crossings in Bezledy, Kuźnica, Terespol and Dorohusk, while trade with Ukraine: in Dorohusk, Korczowa and Medyka.

In terms of significance for the trade with particular countries there were no significant changes, either. In trade with Russia the significance of the crossing in Hrubieszów/Zosin increased (22\% of trade through this crossing in export and $47 \%$ in import). 
Table 4. Foreign trade turnover according to borders of clearance and border crossing points in '000 USD in 2005

\begin{tabular}{|c|c|c|c|c|c|c|c|}
\hline \multicolumn{2}{|c|}{ Border crossing point } & \multicolumn{2}{|c|}{ Belarus } & \multicolumn{2}{|c|}{ Russia } & \multicolumn{2}{|c|}{ Ukraine } \\
\hline & & Export & Import & Export & Import & Export & Import \\
\hline \multirow{3}{*}{ Russia } & $\begin{array}{l}\text { Gronowo/ } \\
\text { /Braniewo }\end{array}$ & 28 & 7891 & 106089 & 59852 & 551 & 45 \\
\hline & Bezledy & 926 & 0 & 445504 & 24689 & 795 & 2 \\
\hline & Gołdap & 0 & 0 & 0 & 6 & 0 & 0 \\
\hline \multirow{6}{*}{ Belarus } & Kuźnica & 222080 & 52967 & 278801 & 104306 & 1189 & 747 \\
\hline & Bobrowniki & 115627 & 6129 & 500637 & 20681 & 1672 & 51 \\
\hline & $\begin{array}{c}\text { Połowce/ } \\
\text { /Czeremcha }\end{array}$ & 931 & 530 & 430 & 105 & 61 & 1 \\
\hline & Terespol & 365586 & 590186 & 702282 & 427653 & 6304 & 6741 \\
\hline & Sławatycze & 3539 & 143 & 1445 & 71 & 31 & 0 \\
\hline & Siemianówka & 879 & 0 & 3735 & 0 & 8 & 0 \\
\hline \multirow{7}{*}{ Ukraine } & Dorohusk & 7052 & 3649 & 33650 & 8604 & 793404 & 152106 \\
\hline & $\begin{array}{c}\text { Hrubieszów/ } \\
\text { /Zosin }\end{array}$ & 1913 & 7546 & 6724 & 54817 & 77022 & 127736 \\
\hline & $\begin{array}{l}\text { Hrebenne/ } \\
\text { /Werchrata }\end{array}$ & 1000 & 0 & 10246 & 1032 & 365807 & 37582 \\
\hline & Korczowa & 1563 & 139 & 19352 & 1837 & 687452 & 121205 \\
\hline & Medyka & 703 & 1897 & 28013 & 104297 & 679733 & 312235 \\
\hline & Krościenko & 4 & 0 & 27 & 0 & 2456 & 0 \\
\hline & Przemyśl & 226 & 0 & 5060 & 0 & 12252 & 0 \\
\hline \multicolumn{2}{|c|}{ Totals } & 750706 & 789120 & 4173921 & 8575651 & 2804001 & 936682 \\
\hline
\end{tabular}

Source: own elaboration on the basis of materials from MF.

In 2007 the bilateral Polish-Russian trade across the Polish-Russian segment of the border amounted to $12.6 \%$ of the Polish export to Russia, and to only $0.7 \%$ of import from Russia. The value of goods transported across this segment of the boundary was insignificant for the trade with the other two eastern partners of Poland.

The Polish-Belarusian segment of the boundary was characterised, on the one hand, by the domination of trade with Belarus $(88.6 \%$ of total exports from Poland and $71.9 \%$ of imports to Poland), and, on the other hand, quite an important-higher than at the Polish-Russian border-contribution to the Polish-Russian trade $(42.1 \%$ of Polish exports and $6.3 \%$ of Polish imports). At the same time, trade with Ukraine across this border segment was marginal $(0.2 \%$ of total Polish exports to Ukraine and $0.5 \%$ of imports).

The Polish-Ukrainian segment of the boundary was characterised by a pronounced-and higher even than in 2005-concentration of direct Polish-Ukrainian 
trade (93.5\% of export to Ukraine and $83.7 \%$ of import from Ukraine). Trade with the two other countries across this segment of the border was quite low, but distinctly higher for Russia- $4.0 \%$ of total export to Russia and 5.0\% of import to Poland, and lower for Belarus-1.5\% of Polish exports to Belarus and 1.9\% of Polish imports from Belarus (Table 5).

Table 5. Foreign trade turnover according to the borders of clearance and border crossings in '000 USD in 2007

\begin{tabular}{|c|c|c|c|c|c|c|c|}
\hline \multirow{2}{*}{\multicolumn{2}{|c|}{ Border crossing point }} & \multicolumn{2}{|c|}{ Belarus } & \multicolumn{2}{|c|}{ Russia } & \multicolumn{2}{|c|}{ Ukraine } \\
\hline & & \multirow{2}{*}{$\begin{array}{r}\text { Export } \\
220 \\
\end{array}$} & \multirow{2}{*}{\begin{tabular}{|r|} 
Import \\
8590
\end{tabular}} & \multirow{2}{*}{$\begin{array}{l}\text { Export } \\
137453\end{array}$} & \multirow{2}{*}{$\begin{array}{r}\text { Import } \\
64033\end{array}$} & \multirow{2}{*}{$\begin{array}{r}\text { Export } \\
501\end{array}$} & \multirow{2}{*}{$\begin{array}{r}\text { Import } \\
0\end{array}$} \\
\hline \multirow{3}{*}{ Russia } & $\begin{array}{l}\text { Gronowo/ } \\
\text { /Braniewo }\end{array}$ & & & & & & \\
\hline & Bezledy & 760 & 1 & 698739 & 32009 & 2410 & 0 \\
\hline & Gołdap & 0 & 0 & 0 & 6 & 0 & 0 \\
\hline \multirow{6}{*}{ Belarus } & Kuźnica & 412801 & 105024 & 748690 & 196924 & 2151 & 484 \\
\hline & Bobrowniki & 161082 & 12028 & 831329 & 17362 & 1482 & 165 \\
\hline & $\begin{array}{c}\text { Połowce/ } \\
\text { /Czeremcha }\end{array}$ & 845 & 198 & 561 & 108 & 24 & 0 \\
\hline & Terespol & 453474 & 693238 & 1206689 & 689621 & 6335 & 8421 \\
\hline & Sławatycze & 764 & 197 & 1053 & 68 & 59 & 0 \\
\hline & Siemianówka & 709 & 0 & 5342 & 0 & 237 & 0 \\
\hline \multirow{7}{*}{ Ukraine } & Dorohusk & 11157 & 1617 & 130352 & 69815 & 1530764 & 294927 \\
\hline & $\begin{array}{l}\text { Hrubieszów/ } \\
\text { /Zosin }\end{array}$ & 2147 & 18460 & 29157 & 454476 & 87237 & 400767 \\
\hline & $\begin{array}{l}\text { Hrebenne/ } \\
\text { /Werchrata }\end{array}$ & 824 & 107 & 26878 & 4667 & 651383 & 125872 \\
\hline & Korczowa & 1394 & 53 & 25253 & 3718 & 1538199 & 197730 \\
\hline & Medyka & 1172 & 1055 & 40021 & 184341 & 1625096 & 503221 \\
\hline & Krościenko & 0 & 0 & 161 & 0 & 23506 & 44 \\
\hline & Przemyśl & 175 & 0 & 14527 & 0 & 14690 & 0 \\
\hline \multicolumn{2}{|c|}{ Totals } & 1161883 & 1127796 & 6640347 & 14348751 & 5850359 & 1818007 \\
\hline
\end{tabular}

Source: own elaboration on the basis of materials from MF.

\section{UNREGISTERED TRADE}

Petty cross-border trade belongs among the characteristic phenomena of the Polish eastern border. That is why, in addition to the official turnover of foreign trade, registered in the Extrastat system, an essential complement to information on the flow of goods across the border might be provided by the study of GUS, which was re-established in 2008 , on the small scale cross-border traffic and trade. Initially, 
this was done for the border segment with Ukraine, then with Belarus, and, since 2010 - for the entire outer boundary of the EU, including the segment with the Kaliningrad district. The study is meant to inquire into the cross-border trade not registered through customs declarations.

The primary subject matter of the study is the value and the structure of expenses borne in Poland by the foreigners and by Poles abroad, for purchasing, inparticular, the food and non-food products, accommodation, and other service. The study concerns also the destination of travel, distance of the locations of accommodation and shopping from the border, frequency of border crossing; and, in case of Polescountry, to which travel was effected, in case of foreigners-country of permanent residence and potential ownership of the Pole's Charter. The study encompasses the foreigners, i.e. persons with permanent residence outside of Poland, leaving Poland, and Poles, residing in Poland, returning home with pas-senger cars, coaches, motorcycles, on foot, and by train (Badanie obszarów transgranicznych 2009).

Data from the Extrastat system for the years 2005 and 2007 are not comparable with the results of the study of GUS (lack of data for these years). Only starting with 2010 direct comparison of results from both kinds of sources will be possible. Yet, already the very first data available for the entire segment of the Polish eastern boundary with the countries from outside of the EU confirm that the dominating purpose of crossing this border, both for Poles and for foreigners, has been shopping. Differentiation concerns the assortment of the goods purchased: foreigners would most often buy construction materials and home appliances, while Poles-fuels, alcoholic beverages and confectionery products (Badanie obrotu towarów i usług... 2010).

As it can be concluded from the data, obtained on the basis of results from the GUS study, the value of expenses borne by Ukrainians in Poland and Poles in Ukraine was significant in relation to the value of the official bilateral trade flows (amounting, respectively, to 141.5 million USD and 24.7 million USD, and being equivalent to roughly $16 \%$ and $8 \%$ of the flows). The situation was similar in terms of the value of expenses at the Polish-Belarusian border: Belarusians spent 71.5 million USD-23\% of the Polish exports to Belarus, while Poles spent 5.0 million USD, i.e. approximately $2 \%$ of imports from Belarus. The significance of mutual shopping visits across the Polish-Russian border in relation to respective trade totals was, however, much smaller. The expenses of foreigners, declaring Russia as the country of permanent residence amounted to 15.2 million USD, while those of Poles-3.0 million USD, corresponding to, respectively, $1 \%$ and $0.07 \%$ of trade flows (it should be remembered that the dominating share of imports from Russia is taken by fuels, transported via pipelines).

\section{SUMIMARY}

The analysis, here presented, shows a relatively complex image of the eastern boundary of Poland in terms of trade in goods, both registered and unregistered. 
A summary of findings could be contained in the following points:

- in 2007 trade with Ukraine took mostly place across the outer boundary of Poland (93.7\% of export and $84.2 \%$ of import), and similarly with Belarus (90.2\% of export and $74.6 \%$ of import over the land segments of the eastern border), while in trade with Russia this share was at $60 \%$ in export and at mere $12 \%$ in import, the remaining flows of goods occurring over different channels;

- the highest concentration of the direct trade flows characterised the trade with Ukraine (93.5\% of total exports in 2007 took place across the Polish-Ukrainian border, and $83.7 \%$ of imports), while somewhat lower concentration of flows of goods occurred in trade with Belarus (88.6\% of total exports and $71.9 \%$ of total imports);

- the highest foreign trade turnover was observed at the Polish-Ukrainian segment of the border (close to 9 billion USD in 2007);

- trade flows across the Polish-Belarusian border are of a different character: side by side with the direct trade with Belarus, this segment constitutes also the main channel for the trade with Russia (in view of the most convenient road connection towards Moscow) - $42.1 \%$ of total exports to Russia takes place across the Polish-Belarusian border, while $12.6 \%$ - across the border with the Kaliningrad district);

- an important influence on the image of border-adjacent areas is exerted by the economic activity of the population and the phenomenon of unregistered trade;

- flows of goods across the eastern border exert an influence on the socioeconomic development of border regions (including the economic situation of the population); - the distribution of flows of goods across the Polish segment of the outer boundary of the European Union ought to be accounted for in the national strategic documents, in particular-in the planning of strategy of developing transport infrastructure within the border areas.

\section{REFERENCES}

Badanie obszarów transgranicznych. Badanie obrotów towarów $i$ ustug w ruchu granicznym. Zeszyt metodologiczny zaopiniowany przez Komisję Metodologiczna GUS (2009), GUS, US Rzeszów, Rzeszów <www.stat.gov.pl> (05. 2010).

Badanie obrotu towarów $i$ uslug $w$ ruchu granicznym na granicy zewnętrznej Unii Europejskiej na terenie Polski w I kwartale 2010 roku. Materiat na konferencje prasowq w dniu 26 maja 2010 r. (2010), GUS, Warszawa <www.stat.gov.pl> (05. 2010).

Grębowiec, M. (2005), Polska statystyka handlu zagranicznego po akcesji do Unii Europejskiej, Wiadomości statystyczne, 11.

Komornicki, T. (2000), Potoki towarowe polskiego handlu zagranicznego a międzynarodowe powiązania transportowe, Prace Geograficzne, 177, IGiPZ PAN, Wydawnictwo Continuo, Wrocław. 